\title{
Analysis Of Factors Affecting The Quality Of Inpatient Medical Records At Royal Prima Hospital Medan 2021
}

\author{
Trionyta Debora $^{1}$, Adrian $^{2 *}$, Mangatas Silaen ${ }^{3}$, Sriwahyuni Nasution ${ }^{4}$, Tan Suyono ${ }^{5}$ \\ $1,2,3,4,5$ Universitas Prima Indonesia \\ ${ }^{*}$ Corresponding Author: \\ Email: adrian@unprimdn.ac.id
}

\begin{abstract}
.
Efforts to strengthen the health services provided to patients rely heavily on the use of high-quality, complete, accurate, and timely data to inform decision-making at the clinical, facility, and policy levels in hospitals. However, evidence of gaps in the quality of medical records is often found. At RSU Royal Prima Medan there are still some incomplete data such as writing the actions that have been done to the patient. The purpose of this study was to analyze the factors that affect the quality of medical records as part of the initiative to strengthen the health care system. The research was conducted using a survey method with an explanatory research design. The research population was 612 people and as many as 100 samples analyzed were taken by stratified random sampling. The univariate test showed that most of the respondents had filled out medical records completely (78.0\%) and on time $(72.0 \%)$, but there were $41.0 \%$ medical records that were inaccurate and did not meet the legal requirements of medical records $(59,0 \%)$. Bivariate analysis with Chi-Square showed that the variables of knowledge $(p=0.001)$, procedures $(p=0.006)$ and supervision $(p=0.003)$ had an effect on the quality of medical records, while equipment had no significant effect. Of the three factors, the most dominant factor influencing the quality of medical records is the knowledge obtained through multiple logistic regression tests with an OR value of 4 times the risk of affecting the quality of medical records. This research is an indication that poor knowledge will affect the quality of medical records so that the Royal Prima Hospital Medan needs to conduct socialization and training to increase the knowledge of health workers (doctors, nurses, medical recorders).
\end{abstract}

Keywords: Quality of medical records, knowledge, supervision, equipment, procedures

\section{INTRODUCTION}

Management of health information in hospitals and other health care facilities continues to grow so that the need for information is very important in decision making for both middle and upper level management. This requires that information management be carried out properly in order to maintain and improve the quality of the health information produced (Siswati, 2017). Hospital medical records are one of the most important components in evaluating the quality of documentation and producing service information to support the achievement of orderly administration as an effort to improve health services. This is essential because effective health quality improvement depends on the smooth, accurate, and precise flow of data between primary, secondary, and regional health facilities and data storage centers (Sharifi et al., 2021). Without good support and a proper medical record management system, orderly administration 
will not succeed so that the quality of medical records plays a very important role in carrying out the quality of medical services provided by hospitals.Currently, medical records are used not only for the primary needs of hospital records, but also for secondary clinical purposes including reporting of hospital service activities, monitoring hospital performance, and research so that medical records must meet the requirements of completeness, accuracy, timeliness and requirements. law (Vahedi et al., 2018).

The advent of electronic medical records has also brought with it an added urgency for standardization so that records can be reliably recorded, stored, and retrieved using computers (Nkhoma and Munthali, 2021).Although there has been an increase in the availability and utilization of medical records, there are still significant gaps in the infrastructure to support the use of medical records in hospitals. The development of science and technology has influenced the community assessment system that demands quality health services. Good and quality health services are reflected not only based on the treatment provided, but also from good medical records as well. The hospital must collect various information properly, manage it properly, and provide it to all decision makers and hospital managers after monitoring, classifying, and making conclusions in a timely manner in order to improve the quality of services provided (Sharifi et al., 2021) (Lestari, 2021).There are still many medical record problems found in Indonesian hospitals. One study showed the problem of recording medical records was the inaccuracy of the data with the percentage of coding accuracy only $74.67 \%$ while the coding inaccuracy reached $25.33 \%$ (Budiyani et al., 2021). In addition, $21 \%$ of the 82 medical records analyzed were found to be inaccurate in the diagnosis code for bronchitis X Hospital in Tangerang (Girato et al., 2020).

Incomplete data recording was also found at Dharma Kerti Tabanan Hospital in $59.48 \%$ of the 232 medical records analyzed (Wirajaya and Dewi, 2020). Another study stated that incompleteness in filling out medical resume sheets was evidence that the appointed officers did not understand (Saud and Umar, 2017.). Another problem that is often found is the inaccuracy of time, such as at the Polyclinic at the Sulaiman Air Force Base Hospital, from 219 medical records there is an inaccuracy in the time of returning to the medical record installation by $52.0 \%$ (Handayani et al., 2021). In addition, Elsa's research at the Level III Hospital Dr. Reksodiwiryo Padang, it was found that the average waiting time for patients at the registration section was 26 minutes 22 seconds (Elsa, 2016). Waiting time for outpatient at General Hospital dr. Achmad Darwis Suliki in 2019 also did not meet the standard where delays in returning medical records to the storage room could cause service to patients to be delayed because the search for files took longer to have an impact on decreasing the quality of health services (Dewi et al., 2020). Hariyanto, et al found that the facilities in the medical record room were inadequate so that it slowed down the administration of medical records (Hariyanto et al., 2019).Several studies related to the factors that affect 
the quality of medical records found by previous studies consist of lack of accuracy and discipline, poor knowledge and attitudes of officers, inadequate medical personnel expertise, few years of service, number of staff which is not proportional to the number of patients, inadequate facilities and infrastructure, the absence of Standard Operating Procedures (SOP) regarding filling out medical resumes, the absence of rewards and punishments, socialization of policies and rules regarding medical resumes has not been maximized, as well as unclear job descriptions.

Budiyani et al., 2021) (Saputra, 2021).The other problems are discipline, work attendance, loyalty and thoroughness. This is found in the registration section, there are still officers who do not fill in the completeness related to patient identification. In addition, there are problems with facilities and infrastructure, namely the lack of filling racks. It was also found that the Standard Operating Procedure (SOP) had not worked well due to the forgetfulness of the officers in carrying out their work (Susanto and Sri Sugiarsi, 2016).Royal Prima General Hospital Medan is one of the type B private hospitals in the city of Medan which received Intermediate Accreditation from the Hospital Accreditation Committee (KARS) in February 2017. The average outpatient visit in one month is 4,858 patients and inpatients 1,287 patients (Royal Prima Hospital Medan, 2018). Based on the results of an initial survey of 30 medical records of inpatients analyzed, there were $78.5 \%$ of completed medical records. This means that $21.5 \%$ of medical record filling is incomplete. The incompleteness was found in filling in the patient's identity $8.3 \%$, signature and name of doctor $5.0 \%$, medical resume $6.6 \%$ and filling in nursing summary $1.6 \%$. The completeness of medical record documents that do not reach $100 \%$ will have an impact on misrepresenting information, hindering the identification of the patient's previous medical history and having the risk of taking the wrong treatment given. Of course this will affect the decline in the quality of health services in hospitals (Rosita et al., 2021).Inaccuracy of data in medical records was also found in $15 \%$, namely in filling in patient identities as much as $5.0 \%$, patient diagnoses $6.6 \%$ and supporting diagnostics $3.3 \%$.

The calculation of the return time of 30 inpatient medical records after the patient returned to the storage rack, it is known that the average length of return is 4.78 days. This is not in accordance with the standard of timeliness of returning inpatient medical records, which must be returned to the storage rack within a maximum of $2 \mathrm{x}$ 24 hours after the patient is discharged. Furthermore, the results of the calculation of the waiting time for 50 inpatients in the medical record file service at the registration section, there is an average of 35.16 minutes even though, based on the Hospital Minimum Service Standards (SPM-RS), the length of time for providing inpatient medical record files is less or equal to 15 minutes. Patient waiting time for the provision of medical record files can be calculated from the time the patient registers at the patient reception area until the medical record file is distributed to the health care unit according to the patient's needs (Sovianita, 2018). The importance of better quality 
in clinical documentation in order to improve health services in hospital management and the discovery of medical record problems at Royal Prima Hospital became the basis for researchers to analyze the factors that affect the quality of inpatient medical records at the hospital.Based on the description on the background, the researcher determines the formulation of the problem in the form of: "Analyze what factors affect the quality of medical records at Royal Prima Hospital Medan?"

\section{LITERATURE REVIEW \\ 2.1 Service Quality}

The service quality of a hospital is a reflection of all the systems that are already running in it. Quality services are not only in medical services, but also in the administration of medical records which is one indicator of the quality of hospital services. Quality is one of the important indicators for companies to be able to exist in the midst of intense competition in the industry. In other words, quality is described as the totality of the characteristics of a product that support its ability to satisfy specified or defined needs (Nasution, 2015). Quality is the suitability of product use (fitness for use) to meet customer needs and satisfaction. The suitability of use is based on the following five main characteristics:

1. Technology, namely strength or endurance.

2. Psychological, namely the image of taste or status

3 . Time, namely reliability

4. Contractual, namely the existence of a guarantee

5. Ethics, namely courtesy, friendly and honest (Juran, 1993)

According to (Deming, 2005), quality is conformity to market or consumer needs. Companies must really understand what consumers need for a product to be produced. If consumers are satisfied, then they will be loyal to buy the company's products in the form of goods and services. According to (Garvin, 1998), quality is a dynamic condition associated with products, people or labor, processes and tasks, and the environment that meet or exceed customer or consumer expectations.

\subsection{Quality of health services}

According to Parasuraman, Zeithaml and Berry in (Gasperz, 2010), stated that service quality is a comparison between the service expected by consumers and the service they receive. According to Lewis and Booms in (Tjiptono, 2011), service quality is a measure of how big the difference between reality and customer expectations for the services received or how well the level of service provided is able to match consumer expectations. The quality of health care or health care is accepted and defined in many senses. The quality of health services can be defined from the medical technical aspect that is only directly related to medical services and patients or the quality of health from a social point of view and the health care system as a whole, including the consequences of administrative, financial, equipment and other health management management (Wijono, 2010). Service quality is perceived as good and 
satisfactory if the service received or perceived by the customer is as expected, if the service received exceeds consumer expectations, then the service quality is perceived as very good and of high quality. Service quality is perceived as bad if the service received is lower than expected. The quality of health services shows at the level of perfection of the appearance of health services that can satisfy users of health services according to the level of satisfaction of the average population, the procedures for its implementation are in accordance with the standards and professional code of ethics that have been established (Wijono, 2011).

\subsection{Dimensions of the quality of health services}

According to Parasuraman, Zeithaml and Berry in (Tjiptono, 2011), there are 5 (five) main dimensions in service quality as follows:

1. Reliability (reliability). Reliability or reliability is related to the company's ability to provide accurate service from the first time without making any mistakes and delivering its services in accordance with the agreed time.

2. Responsiveness (responsiveness). Responsiveness relates to the willingness and ability of employees to help customers and respond to their requests, as well as inform when services will be provided and then provide services quickly.

3. Guarantee (assurance). Behavior of employees or employees who are able to foster consumer or customer confidence in

companies and companies can create a sense of security for their consumers. Assurance also means that employees are always courteous and possess the knowledge and skills required to deal with any customer inquiries or concerns.

4. Empathy (empathy). Empathy states that the company understands the problems of its customers and acts in the interests of consumers, and gives personal attention to consumers and has comfortable operating hours.

5. Physical evidence (tangible). With regard to the attractiveness of physical facilities, complete equipment/equipment and clean materials are used, and the appearance of employees is neat (Tjiptono, 2011).

\subsection{Quality of Medical Records}

According to (Huffman, 1994), medical records are facts related to the patient's condition, past and current medical and medical history written by health professionals who provide services to these patients. According to (Permenkes, 2013), medical records are files that contain records and documents about patient identity, examination, treatment, actions and other services to patients at health care facilities. According to the Hospital Accreditation Committee, medical records contain adequate or sufficient information to identify patients, support diagnoses, justify or justify treatment, document examinations and treatment results and improve service continuity among health care practitioners (KARS, 2012). Medical records have a very broad meaning, not only recording, but also as a system for organizing medical records, where recording activities are one of the activities of organizing medical records. Organizing medical records is a process of activities that begins at the time the patient 
is received at the hospital, continues with recording medical records while receiving health services and continues with the handling of medical records which includes the administration, storage and release of medical records from storage racks to serve requests/borrows from customers. Patients or for other purposes in accordance with applicable regulations.

The purpose of medical records is to support the achievement of administrative order in the context of efforts to improve health services in hospitals. Without the support of a good and correct medical record management system, there will not be an orderly hospital administration as expected. Meanwhile, administrative order is one of the determining factors in health service efforts in hospitals (Depkes RI, 2006).According to (Ministry of Health RI, 2006), the procedure for organizing medical records in hospitals, namely: Patient acceptance. The procedure for accepting patients who will go to the polyclinic or who will be treated is part of the hospital service procedure system. It can be said that this is where the first service received by the patient when he arrives at the hospital, so it is not an exaggeration to say that it is in this reception procedure that a patient gets a good or bad impression of the services of a hospital. Procedures for serving patients can be considered good if they are carried out by officers with a friendly, polite, orderly and responsible attitude.

Recording of medical service activities. The hospital as a health service facility that provides outpatient and inpatient services is required to make medical records. The person in charge of filling out the medical record is:

1. General practitioners, specialist doctors, dentists and specialist dentists who serve patients in hospitals.

2. A visiting doctor who treats patients in the hospital.

3. Residents who are carrying out clinical clerkships.

4. Nursing medical personnel and non-maintenance medical personnel who are directly involved in, among others: nurses, dental nurses, midwives, clinical laboratory personnel, nutrition, anesthesiologists, X-ray administrators, medical rehabilitation and so on.

5. For foreign doctors who transfer medical technology in the form of action/consultation to patients, the doctor who makes the patient's medical record is the doctor appointed by the hospital director.

Medical records are made immediately and completely completed after the patient receives service with the following conditions:

1. Every consultation action carried out on a patient, within 24 hours at the latest, must be written in the medical record sheet.

2. All records must be signed by a doctor or other health worker in accordance with their authority and clearly written and dated.

3. Records made by medical students and other students are signed and are the responsibility of the treating doctor or by the supervising doctor.

4. Records made by residents must be known by their supervising physician. 
5. The treating doctor can correct writing errors and do so at the same time and initialed.

6. Deletion of writing in any way is not permitted or is not permitted.

\subsection{Research Hypothesis}

Based on the conceptual framework, theoretical basis and research objectives and background, the hypotheses of this research are:

1. There is an effect of knowledge of health workers on the quality of inpatient medical records at General Hospital of Royal Prima Medan.

2. There is an effect of equipment on the quality of inpatient medical records at General Hospital of Royal Prima Medan..

3. There is an effect of procedure on the quality of inpatient medical records at General Hospital of Royal Prima Medan.

4. There is an influence of supervision on the quality of inpatient medical records at General Hospital of Royal Prima Medan.

5. There is the most dominant factor influencing the quality of inpatient medical records at General Hospital of Royal Prima Medan.

\section{METHODS}

The research design used in this study is a survey research type of explanatory research. Explanatory research is research that is used to explain causal relationships between variables through hypothesis testing which is formulated or often referred to as explanatory research (Singarimbun \& Effendi, 2016). This study aims to explain the effect of knowledge, equipment, procedures, and supervision on the quality of inpatient medical records at General Hospital Royal Prima Medan, 2021". This research was conducted at General Hospital Royal Prima Medan. The reason for choosing the research location was because it was found that the quality of inpatient medical records was still not good and similar research in this hospital had never been done.This research was carried out for 1 (one) month, starting from June 2021 to September 2021. The population in this study were all doctors, nurses and medical record officers at General Hospital Royal Prima Medan totaling 612 people. The sample is part of the number and characteristics possessed by the research population. The sample size in this study was determined as many as 100 people. The sampling technique was stratified random sampling by dividing the population into proportionally homogeneous groups (strata), namely 25 doctors, 67 nurses and 8 medical record officers, from each strata the samples were taken randomly (randomly).

\section{DISCUSSION}

The quality of hospital service quality management is the basis for describing and strengthening the health services provided to patients and this process is very dependent on the quality of recording medical records provided by health workers, medical support and other personnel to assist in making decisions about appropriate 
therapy, action and diagnosis. given. The results of this recording are also an indicator of the quality of medical records which are included in one of the hospital accreditation assessment standards. Duties and responsibilities of the medical record unit and medical staff are the management of medical record contents such as completeness of contents, retention policies, destruction and confidentiality, ownership, utilization and organization. This study uses four variables that are estimated to be factors that affect the quality of medical records at the Royal Prima General Hospital Medan, namely the knowledge of health workers, technological facilities/equipment used, medical record procedures and supervision carried out to monitor the process of administering medical records. The results of observations made on 100 health workers at Royal Prima Hospital showed that filling in medical records in general was complete $(78.0 \%)$ and on time $(<2$ days) $(72.0 \%)$, only that the accuracy of the data filled in was still lacking. .

This can happen due to several factors. One of the factors described in the results of the study is the lack of training for health workers regarding medical records. Of the 100 respondents analyzed, $92.0 \%$ of respondents had never received training on medical records, even though there were $31.0 \%$ of respondents who had worked for $>$ 8 years. Eight people who received training were only medical record officers, even though the mandatory target in medical record training was not only medical record officers, but also doctors and nurses who provided services to patients (Budiyani et al., 2021). This can be seen from the medical record data from the research, which are incomplete, mostly found in the patient's identity, doctor's signature, medical summary and filling in the nursing summary. Previous research has also found problems that often arise in filling out medical records such as incomplete filling processes and doctor writing that is less specific about diagnosis (Ridho et al., 2013). S Shariffi, 2021 found that there was a significant influence between the behavior of doctors and the completeness of writing medical record data on medical resume sheets (Shariffi et al., 2021). The inaccuracies found in the recording of medical records indicate that they may occur because the efforts of health workers to achieve maximum performance are still lacking, such as research which reveals that officers have an effort to achieve relatively low performance in filling out medical record documents, which is $75 \%$ (Rosita et al. , 2021).

Most of the medical records analyzed did not meet legal requirements (59.0\%). The basic reason for this requirement based on the results of a survey conducted, respondents' knowledge of medical records was still lacking by $47.0 \%$, especially knowledge of the Minister of Health's medical record, how to sort medical record forms, writing danger signs recorded on the action form and recording patient consultation actions. After doing the bivariate test to see the relationship between variables, knowledge statistically affects the quality of medical records.Some health workers who have good knowledge are not accompanied by good filling of medical records. This happens because even though the level of knowledge of doctors and 
nurses in filling out medical records is good, if it is not based on a strong will, it is not necessarily writing quality medical records. Tandy's research in 2018 revealed that psychological factors (attitudes and motivations) had an effect on compliance with filling out medical record data (Tandy, 2018). In general, the description of the condition of the equipment that supports the administration of medical records is still lacking (63\%). Inadequate equipment based on respondents' opinions, namely the number of medical record storage cabinets in the inpatient room is less supportive and there is no register book available according to hospital needs so that many medical records cannot be compiled and retrieved quickly when needed.

Previous research describes hospitals that already have an in-active RM storage room, but do not yet have an in-active medical record storage rack (Ritonga and Rusanti, 2018). Research conducted by (Susanto, 2016) related to equipment or facilities and infrastructure that can support the process of medical record services at PKU Muhammadiyah Surakarta Hospital is good and refers to technical guidelines for class B hospital buildings but the quantity and use is still not optimal, namely still it was found that there was a lack of filing racks for storing medical record documents which resulted in medical record documents not being included in the filing rack. Then the Standard Operating Procedure (SOP) in the management of medical records. This inadequate equipment is not the basic reason for the decline in the quality of medical records at the Royal Prima Hospital Medan, because even though the equipment is lacking, the percentage of health workers who fill out medical records properly is higher than those who fill out poor medical records. The supervision carried out on the organization of medical records is also still lacking. Research conducted by Pemberiadi in the Medical Record Unit of Dr. General Hospital Hasan Sadikin Bandung in 2015 showed that in the supervision process it did not refer to the standard merit system and corrective actions were taken if there were medical record processing personnel who protested against the value of their merit system. Standard Operating Procedure (SOP). This study revealed something different from several previous journals which showed a significant influence between these four factors on the quality of medical records (Elsa, 2016; Ridho et al., 2013; Rosita et al., 2021) (Vahedi et al., 2018) .

As with the knowledge variable, there is a significant relationship between procedures and supervision of the quality of medical records at Royal Prima Hospital.Qualitative research conducted by Hafid in 2018 found that the limited time in filling out medical records for health workers who were less than optimal in the organizing process greatly affected the quality (Hafid, 2018). Previous studies have found that incentives play an important role in changing attitudes and behavior (Murphy, 2015). Another study by Saravi et al. at Mazandaran University Hospital that the most important reason for incomplete medical records is that doctors and surgeons believe that the medical/surgical care required for patients is very important, but documentation regarding treatment is not considered part of the treatment process. In teaching hospitals, this problem may be due to a lack of supervision (Asghari et al., 
2016). Quality medical records are medical records that are filled out completely, accurately, accurately and well documented. Therefore, supervision of medical record personnel is very important in improving performance so that it is not detrimental to patients and hospitals as well as being one of the successes in managing a company or home Sickness depends on several factors, one of which is the human resource factor, namely health workers. The existence of a relationship between knowledge, procedures, and supervision of the quality of medical records is an indication of the lack of quality of medical records and if these factors are not addressed for a long time can significantly reduce the quality of health services so that monitoring and evaluation of the quality of medical records must be carried out in hospitals. Royal Prima General Hospital.

\section{CONCLUSSION AND RECOMMENDATION}

\subsection{Conclussion}

Based on the results of the study, it can be concluded:

1. Knowledge has a significant effect on the quality of inpatient medical records, where the results of statistical tests show that the value of $p=0.001<0.05$.

2. The procedure has a significant effect on the quality of inpatient medical records, where the results of statistical tests show that the value of $p=0.006<0.05$.

3. Supervision has a significant effect on the quality of inpatient medical records, where the results of statistical tests show that $p=0.003<0.05$

4. There is no effect of equipment $(p=0.192<0.05)$ on the quality of inpatient medical records at General Hospital Royal Prima Medan.

5. Knowledge is the dominant variable that affects the quality of medical records with Exp (B) 4.46. Good knowledge of medical records has the opportunity to have medical record quality 4.6 times higher than respondents who have less knowledge.

\subsection{Recommendation}

The suggestions that can be given based on the results of this study are:

\section{Royal Prima General Hospital Medan.}

The Royal Prima Medan General Hospital is advised to provide continuous training to health workers, both medical record officers, doctors and nurses related to the process of filling out the completeness of medical records in order to increase understanding and ability in the overall medical record process at the Royal Prima Medan General Hospital. The results of this study can also be a suggestion that the supervision of doctors and medical record officers by the medical committee and nurses by the nursing committee is increasingly improved to avoid incomplete data in the medical record. It is recommended that the hospital implement regular supervision with evaluations every week, every month, every six months, and every 1 year at the Royal Prima General Hospital Medan so that inpatient medical records are of higher quality, namely medical records that are complete, accurate, returned on time, and meet legal requirements. 
2. Health workers (medical record officers, doctors, nurses) at General Hospital Royal Prima Medan

Health workers, both medical record officers, doctors, nurses, are advised to be more thorough and detailed in filling out inpatient medical records in accordance with the procedures determined by the Royal Prima Medan General Hospital so that the quality of medical records does not raise any doubts, because they are filled out completely, accurately, accurately. time and meet legal requirements.

\section{The next researcher}

Future researchers are expected to examine more sources and references related to the quality of medical records in hospitals. In the process of collecting data, a wider sample and method should be used to obtain a more optimal study of factors related to the quality of medical records.

\section{REFERENCES}

[1] Asghari, Z., Mardanshahi, A., Farahabadi, E.B., Siamian, H., Gorji, A.M.H., Saravi, B.M., Rezazadeh, E., Paymard, S.P., 2016. The quantitative study of the faculty members performance in documentation of the medical records in teaching hospitals of Mazandaran University of medical sciences. Mater. Sociomed. 28, 292.

[2] Budiyani, V.Y., Wariyanti, A.S., Wahyuningsih, S., 2021. Literature Review Faktor Yang Mempengaruhi Ketepatan Petugas Koding Diagnosis Berdasarkan Unsur 5M. Indones. J. Heal. Inf. Manag. 1, 14-20.

[3] Dewi, S., Machmud, R., Lestari, Y., 2020. Analisis Waktu Tunggu Rawat Jalan di Rumah Sakit Umum Daerah Dr Achmad Darwis Suliki Tahun 2019. J. Kesehat. Andalas 8.

[4] ELSA, F., 2016. Analisis Lamanya Waktu Tunggu Pelayanan Rekam Medis Di Pendaftaran Rawat Jalan Rumah Sakit Tk. Iii Dr. Reksodiwiryo Padang Tahun 2016.

[5] Girato, K., Ambarwati, A., Hosizah, H., 2020. Analisis Ketepatan Kode Diagnosis Penyakit Bronchitis Pasien Rawat Jalan Dengan Metode Fishbone Di Rumah Sakit X Tangerang. 4th Proceeding Perspekt. Implementasi FHIR. ISBN 978-623-6566-34-3 4.

[6] Handayani, E., Nur'ilmi, W., Sari, I., 2021. Analisis Pengembalian Rekam Medis Rawat Jalan Terhadap Kecepatan Pendistribusian ke Poliklinik Di RSAU Lanud Sulaiman. Cerdika J. Ilm. Indones. 1, 939-946.

[7] Hariyanto, E., Wahyuni, S., Iqbal, M., 2019. Aplikasi Rekam Medis Pada Klinik Pratama Darul Amin Berbasis Web, in: Prosiding SiManTap: Seminar Nasional Matematika Dan Terapan. pp. 697-701.

[8] Lestari, M.S., 2021. Analisis Faktor Penyebab Kerusakan Dokumen Rekam Medis Berdasarkan Pendekatan Faktor Manajemen 6m Di Rs: Literature Review.

[9] Murphy, B., 2015. The impact of reward systems on employee performance.

[10] Nkhoma, D.B., Munthali, K.G., 2021. Investigation of Key Factors Affecting Quality of Patient Data from National Antiretroviral Therapy Electronic Medical Record System in Malawi. Malawi J. Sci. Technol. 13, 25-44. 
[11] Ridho, K.M., Rosa, E.M., Suparniati, E., 2013. Analisis faktor-faktor yang mempengaruhi kepatuhan pengisian rekam medis di Rumah Sakit Gigi dan Mulut Pendidikan UMY. JMMR (Jurnal Medicoeticolegal dan Manaj. Rumah Sakit) 2.

[12] Ritonga, Z.A., Rusanti, S., 2018. Gambaran Sistem Penyelenggaraan Rekam Medis di Rumah Sakit Umum Bunda Thamrin Tahun 2018. J. Ilm. Perekam dan Inf. Kesehat. Imelda 3, 498-509.

[13] Rosita, R., Rizky, A.P.K., Afifah, N.N., 2021. Faktor Penyebab Ketidaklengkapan Dokumen Rekam Medis Rawat Inap Pada Kasus Single Live Birth, in: Seminar Informasi Kesehatan Nasional (SIKesNas). pp. 391-399.

[14] Saputra, O.H., 2021. Literature Review-Analisis Faktor Ketidaklengkapan Pengisian Resume Medis Pasien Rawat Inap. Infokes J. Ilm. Rekam Medis dan Inform. Kesehat. $11,53-56$.

[15] Saud, N.P., Umar, K.,2017. Tinjauan Resume Medis Pada Berkas Rekam Medis Pasien Rawat Inap Di Rumah Sakit Umum Daerah (RSUD) Toto Kabila Kabupaten Bone Bolango Provinsi Gorontalo.

[16] Sharifi, S., Zahiri, M., Dargahi, H., Faraji-Khiavi, F., 2021. Medical record documentation quality in the hospital accreditation. J. Educ. Health Promot. 10.

[17] Siswati, M.Y., 2017. Manajemen Mutu Informasi Kesehatan II: Akreditasi dan Manajemen Resiko (Health information quality management II: Accreditation and risk management). Artic. Indones. Jakarta Pus. Pendidik. Sumber Daya Mns. Kesehat.

[18] Sovianita, R., 2018. Implementasi Peraturan Menteri Kesehatan (Permenkes) Nomor 269 Tahun 2008 Tentang Rekam Medis Di Puskesmas Kota Padang. J. Progr. Pascasarj. 12. Susanto, A., Sri Sugiarsi, S.K.M., 2016. Penerapan Manajemen Mutu Pelayanan Di Unit Rekam Medis Rumah Sakit PKU Muhammadiyah Surakarta.

[19] Tandy, D.Y., 2018. Analisis Kepatuhan Pengisian Berkas Rekam Medis Di Rumah Sakit Daerah (Rsd) Kalisat Jember Tahun 2017.

[20] Vahedi, H.S., Mirfakhrai, M., Vahidi, E., Saeedi, M., 2018. Impact of an educational intervention on medical records documentation. World J. Emerg. Med. 9, 136.

[21] Wirajaya, M.K.M., Dewi, N.M.U.K., 2020. Analisis Ketidaklengkapan Rekam Medis Pasien Rawat Inap di Rumah Sakit Dharma Kerti Tabanan. J. Adm. Rumah Sakit Indones. 6 . 